City of Saints 
THE MIDDLE AGES SERIES

Ruth Mazo Karras, Series Editor

Edward Peters, Founding Editor

A complete list of books in the series is available from the publisher. 


\section{City of Saints}

Rebuilding Rome in the

Early Middle Ages

Maya Maskarinec

\section{PENN}

University of Pennsylvania Press

Pbiladelpbia 


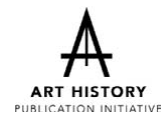

This book is made possible by a collaborative grant from the Andrew W. Mellon Foundation.

Copyright ( 2018 University of Pennsylvania Press

All rights reserved. Except for brief quotations used for purposes of review or scholarly citation, none of this book may be reproduced in any form by any means without written permission from the publisher.

Published by

University of Pennsylvania Press

Philadelphia, Pennsylvania 19104-4112

www.upenn.edu/pennpress

Printed in the United States of America on acid-free paper

$\begin{array}{llllllllll}10 & 9 & 8 & 7 & 6 & 5 & 4 & 3 & 2 & 1\end{array}$

\section{Library of Congress Cataloging-in-Publication Data}

Names: Maskarinec, Maya, author.

Title: City of saints : rebuilding Rome in the early Middle Ages / Maya Maskarinec.

Other titles: Middle Ages series.

Description: 1st edition. | Philadelphia : University of Pennsylvania Press, [2018] | Series:

The Middle Ages series | Includes bibliographical references and index.

Identifiers: LCCN 2017046025 | ISBN 978-0-8122-5008-4 (hardcover : alk. paper)

Subjects: LCSH: Christian saints-Cult-Italy-Rome-History-To 1500. |

Christianity-Social aspects-Italy—Rome-History-To 1500. | Christianity—Social aspects—Europe-History-To 1500. | Rome (Italy)—Church history. | Rome (Italy)— History—476-1420.

Classification: LCC BX2333 .M38 2018 | DDC 235/.2094563209021-dc23

LC record available at https://lccn.loc.gov/2017046025 